\title{
Company Life Cycle and Capital Structure of Manufacturing Sector in the Consumer Goods Industry
}

\author{
SULAEMAN R. NIDAR ${ }^{1}$, RIZKI A. P. UTOMO ${ }^{2}$ \\ ${ }^{1}$ Lecturer, Department of Management and Business, Universitas Padjadjaran, Bandung 40132, Indonesia \\ ${ }^{2}$ Alumnae, Undergraduate Study Program Management, Universitas Padjadjaran, Bandung 40132, Indonesia \\ Email correspondence: sulaeman.rahman@fe.unpad.ac.id
}

\begin{abstract}
Determination of the optimal capital structure needs to be done by each company. Capital structure is the balance or ratio between foreign capital and equity capital. One proxy of capital structure is leverage. The well-known theory in determining the leverage or capital structure is the pecking order theory. This theory explains that the company will use the funds to have a safer risk in advance in the determination of corporate leverage. There are many variables that affect the determination of a company's leverage, so there is no single and standard model in determining the leverage or capital structure of the company. One variable that adds the explanation of the determination of a company's leverage is the life cycle as proposed by Dickinson (2011). The difference of company life cycle is differentiated by the company's cash flow including cash flow from operating, financing, and investment. This study aims to determine whether the company life cycle can explain the determination of leverage or capital structure of the company, and find out the influence of other variables such as profitability, liquidity, size of firm, non-debt tax shield, asset tangibility, and growth opportunities on the leverage or capital structure of the company. This study was conducted in the consumer goods companies in 2012 and 2013. This study uses regression with dummy variables. The results showed that in 2012 and 2013 , the variable of the life cycle can be one of the variables that can explain leverage the company's decision. The variables that affect the leverage are profitability, liquidity, non-debt tax shield, asset tangibility, and growth opportunities. The variable which has no effect on leverage is the size of the company.
\end{abstract}

Key words: Leverage, Consumer Goods, Company Life Cycle, Profitability, Liquidity, Company Size, Non-Debt Tax Shield, Asset Tangibility, Growth Opportunities.

\section{Siklus Hidup Perusahaan dan Struktur Modal Sektor Manufaktur di Industri Barang-barang Konsumsi}

\author{
Abstrak
}

Penentuan struktur modal yang optimal perlu dilakukan oleh masing-masing perusahaan. struktur modal adalah keseimbangan atau rasio antara modal asing dan modal ekuitas. Satu proxy dari struktur modal adalah leverage. Teori ini terkenal dalam menentukan leverage atau struktur modal adalah teori pecking order. Teori ini menjelaskan bahwa perusahaan akan menggunakan dana memiliki risiko yang lebih aman di muka dalam penentuan leverage perusahaan. Ada banyak variabel yang mempengaruhi penentuan leverage perusahaan, sehingga tidak ada model tunggal dan standar dalam menentukan leverage ataustruktur modal perusahaan. Salah satu variabel yang menambahkan penjelasan penentuan leverage perusahaan adalah siklus hidup seperti yang diusulkan oleh Dickinson (2011). Perbedaan siklus hidup perusahaan dibedakan oleh arus kas perusahaan termasuk arus kas dari operasi, pembiayaan, dan investasi. Penelitian ini bertujuan untuk mengetahui apakah siklus hidup perusahaan dapat menjelaskan penentuan leverage atau struktur modal perusahaan, dan mengetahui pengaruh variabel lain seperti profitabilitas, likuiditas, ukuran perusahaan, nonhutang tax shield, aset tangibility, dan peluang pertumbuhan di leverage atau struktur modal perusahaan. Penelitian ini dilakukan di perusahaan barang konsumsi pada tahun 2012 dan 2013. Penelitian ini menggunakan regresi dengan variabel dummy. Hasil penelitian menunjukkan bahwa pada tahun 2012 dan 2013, variabel dari siklus hidup dapat menjadi salah satu variabel yang dapat menjelaskan keputusan leverage perusahaan. Variabel yang mempengaruhi leverage adalah profitabilitas, likuiditas, non-utang pajak perisai, tangibility aset, dan peluang pertumbuhan. Variabel yang tidak berpengaruh pada leverage adalah ukuran perusahaan.

Kata kunci: Leverage, Barang-barang konsumsi, Siklus Hidup Perusahaan, Profitabilitas, Likuiditas, Ukuran Perusahaan, Non-Hutang Tasx Shield, Tangibility Aset, Peluang Pertumbuhan. 


\section{INTRODUCTION}

High-growth companies will make the company reconsider their capital structure which may lead to the addition of new debt. An increase in the company's debt ratio will be different and it can be affected by sector basis according to its life cycle.

The companies at the stage of introduction have a higher debt ratio compared to companies at the growth and mature stage. In addition, the companies at the growth stage have a higher debt ratio than the companies are at the mature stage but lower when compared to the companies at the stage of introduction.

The companies at the mature stage have a lower debt ratio compared to the companies at the stage of introduction and mature. This shows that the companies at the stage of introduction use a higher debt to conduct their business compared to the companies at the growth and mature stage.

This research was carried out in the consumer goods industry sectors listed on the Indonesia Stock Exchange (IDX). The selection of consumer goods industry sector is based on the notion that the industry has a higher growth among others. Consumer goods industry in 2009 worth 671.31 billion rupiahs and rose to $1,782.09$ billion rupiahs in 2013 . The increase was $162 \%$ within five years. With the high and stable growth each year, the consumer goods sectors will require greater funding to carry out their business activities.

\section{LITERATURE REVIEW}

Capital structure decisions cannot be separated from the policy of corporate debt since the determination of capital structure will be represented by the policy of debt (leverage) of the company. Determination of the company's leverage is very difficult when the aim is to produce the optimal capital structure and enhance shareholder value. Determining the leverage is associated with the life cycle of the company to get a more definitive answer to its determination.

The life cycle of the company, according to Dickinson (2011: 33), is divided into five stages, namely introduction, growth, mature, shake out, and decline. Bulan and Yan (2009), in the Carlo et al (2012), explained the factors such as size, age, profitability, tangible assets, and retained earnings which are affected by the life cycle of the company. DeAngelo et al (2006) stated that dividends are affected by the life cycle of the company, leading to effect the company's debt capacity.

Profitability has an important role in determining the leverage of the company. When the companies have a high profitability, they will likely reduce the debt in running their business as claimed by Myers (1993) and Strebulaev (2007). According to Brigham and Houston (2004: 505), the companies with a very high rate of return will allow them to finance most of their funding needs with internally generated funds. Therefore, the higher the profitability is, the lower the debt becomes.

Liquidity is one of the factors taken into account in capital structure decisions. The companies that have a high liquidity tend to not use debt financing. This is because the companies with high liquidity have a large internal fund, so they will first use internal funds to finance the investment before using external financing through debt. According to the Bennet and Donnelly (1993), Ozkan (2001), and Akdal (2011), when the liquidity is high, the leverage will decline.

When an asset is considered as collateral of the debtor, the size of the company can be seen as a sign of the ability of the company by the creditors (Fama and French, 2005). Ramlall (2009) suggested that large firms have lower leverage due to the degree of information asymmetry and a higher complex structure. The large companies are associated with a strong financial resource, so they finance their needs with retained earnings. The size of the company negatively related to leverage as stated by Hadianto (2008), Mela (2011), Ramlall (2009).

Non-debt tax shield is the replacement of the tax benefits for the companies that owe (DeAngelo and Masulis, 1980 and Ramlall, 2009). DeAngelo and Masulis (1980) in Titman and Wessels (1988) showed a model of an optimal capital structure, the influence of corporate tax, personal tax and non-debt on the company's tax shields. The study found that the tax 
deductibility of depreciation and investment tax credits resulted in tax benefits in debt financing. Nondebt tax shield that becomes a proxy of benefit apart from debt will be negatively related to leverage.

Assets are part of the company used for operational activities. The companies with a high level of fixed assets are generally large companies and able to issue shares at a fair price and do not use debt to finance investment (Harris and Raviv, 1991 in Christianti, 2006). Asset tangibility will be negatively related to leverage.

Growth opportunity is a key factor affecting the financing of companies (Fama and French, 2005). Christianti (2006) stated that the pecking order hypothesis has two signals: the companies with a high growth rate will tend to keep and maintain a debt ratio at a low level (negative signal) or companies with a high growth rate will be expanded by using funds from external in the form of debt (positive signal). In this study, the growth of the company is assumed to have a positive effect on leverage as stated by Frank and Goyal (2008).

Based on the description of the relationship among the factors of the life cycle, profitability, liquidity, the size of the firm, non-debt tax shield, asset tangibility and growth opportunity and leverage, the hypothesis can be formulated as follows:

$\mathrm{H} 1$ : Life cycle affects the company's leverage.

H2: Profitability negatively affects the company's leverage at the Introduction, Growth, and Mature stage.

H3: Liquidity negatively affects the company's leverage at the Introduction, Growth, and Mature stage.

H4: Firm size negatively affects the company's leverage at the Introduction, Growth, and Mature stage.

H5: Non-debt tax shield negatively affects the company's leverage at Introduction, Growth, and Mature stage.

H6: Asset tangibility negatively affects the company's leverage at Introduction, Growth, and Mature stage.

H7: Growth opportunity positive influences the company's leverage at Introduction, Growth, and Mature stage.

\section{RESEARCH MRTHODS}

The method used in this study is the verification method with a quantitative approach. This study is aimed at testing the hypothesis by using statistical calculations. This research is to examine the influence of the variables of companies' capital structure (X) included at the lifecycle stages (introduction, growth, and mature) on the value of debt (Y). The authors then investigated further by collecting, processing, analyzing, and interpreting data in the statistical hypothesis testing, so the results can be verified.

Another technique used in data processing is the use of dummy variables. Dummy variables used to determine whether the grouping of companies based on the life cycle of introduction, growth and mature decisions will affect the capital structure of a company.

\section{RESULTS AND DISCUSSION}

The analysis is based on financial data of 26 companies included in the consumer goods industry sector in 2012-2013. Description of variables in the descriptive statistics includes the minimum, maximum, mean and standard deviation presented in the table of descriptive statistics. Descriptive statistics and ratings are associated with the collection of data. Descriptive statistics describe the character of the sample used in the study. An explanation of the study variables includes profitability, liquidity, the size of the firm, non-debt tax shield, tangibility assets, growth opportunities, and a dummy variable of the life cycle the company.

The variable of leverage is the ratio of total debt to total assets and represents the company's capital structure. The average value of leverage for companies at introduction stage is 0.645566 , meaning that in average, the companies use debt of $64.56 \%$ of their total assets. This value is greater compared to the companies at growth and mature stage of 0.493625 and 0.337563 respectively. The smallest value of the leverage of 0.130592 owned by PT Mandom Indonesia Tbk in 2012. At the mature stage of the life cycle, its total debt is Rp.164.751.376.547. The biggest value of leverage worth 0.986079 owned by Merck Sharp Dohme Pharma Tbk in 2013. At the stage 
of introduction, its total debt is Rp.736.010.824.000.

Profitability is the company's ability to make a profit. The average profitability value of companies at the mature stage is 0.238551 . This means that in average, the companies are able to generate $23.86 \%$ profit of the total assets. The value is greater when compared to the companies at growth and introduction stage of 0.111220 and 0.028823 respectively. The smallest value of profitability is -0.108488 or $-10.85 \%$ owned by PT Bentoel International Investama Tbk in 2013, occurred at the introduction stage of the life cycle. The highest profitability value worth 0.855666 or $85.57 \%$ owned by PT Unilever Indonesia Tbk in 2013, occurred at the mature stage of the life cycle with a total value of operating income of Rp.1.524.924.000.000.

Liquidity is the ability of a company to meet its shortterm obligations. The average value of liquidity of companies at mature cycle is 3.332491 , meaning that the companies' ability to meet the short-term liabilities is $333.25 \%$ of their short-term assets. The value is greater compared to the companies at the growth and introduction cycle with the value of 1.798976 and 1.526174 respectively. The smallest liquidity value of 0.535311 or $53.53 \%$ is owned by PT Multi Bintang Indonesia Tbk in 2013 which was at the mature stage of the life cycle. The cause of this liquidity value is because the company only had current assets worth Rp.426.471.000.000 and short-term debt of Rp. 796.679 billion. The highest liquidity value worth 7.726538 or $772.65 \%$ is owned by PT Mandom Indonesia Tbk in 2012 which was at a mature stage. Its value of short-term debt is Rp.99.477.347.026 and current assets of Rp.768.615.499.251

The size of the company is calculated by using the natural log of total assets (In total assets). The average score of company size is 28.12682 worth Rp.6.960.335.985.008. The smallest score of company size is 25.27668 owned by PT Kedaung Indah Tbk in 2012 with a total asset of Rp.94.955.970.131. The largest score of company value is 31.98892 owned by PT Indofood Sukses Makmur Tbk in 2013 with a total asset of Rp.78.092.789.000.000.

Non-Debt Tax Shield is a non-cash charge leading to tax savings. The average value of non-debt tax shield at companies with the mature cycle is 0.244459 , meaning that the average companies in the mature stage were capable of using non-cash charge of $24.46 \%$ for taxes and making savings as capital to reduce debt. The value is greater compared to the companies at growth and introduction stage with the value 0.186978 and 0.183770 respectively. The smallest value of non-debt tax shield of 0.011977 or $1.197 \%$ is owned by PT Merck Tbk in 2012 at a mature stage and the value of its accumulated depreciation of Rp.6.820.193.000. The greatest value of non-debt tax shield worth 0.502409 or $50.24 \%$ is owned by PT Multi Bintang Indonesia Tbk which was at mature life cycle in 2012. The value of accumulated depreciation worth Rp. 578.799 billion.

Asset tangibility is the ratio of fixed assets to total assets. The average value of asset tangibility at companies with growth stage is 0.467511 , meaning that the companies' fixed asset ratio to total assets is $46.75 \%$. The value is greater compared to the companies at the mature and introduction stage with the value of 0.413777 and 0.356346 respectively. The smallest value of asset tangibility of 0.137167 or $13.72 \%$ is owned by PT Delta Djakarta Tbk in 2013 which was at the mature stage with the value of fixed assets of Rp.118.929.799.000 and total assets of Rp.867.040.802.000. The greatest value of the asset tangibility worths 0.629815 or $62.98 \%$ is owned by PT Multi Bintang Indonesia Tbk in 2012 which was at the mature stage with the value of fixed assets of Rp.725.577.000.000 and total assets of Rp.1.152.048.000.000.

Growth opportunity is an assessment of the companies' outlook in the future represented by the ratio of market value to book value. The average value of growth opportunity at companies with the mature stage is 8.023855 , meaning that the companies had the growth prospect of $802.39 \%$. The value is greater compared to the companies at the growth and introduction stage with the value of 2.875988 and 2.367267 respectively. The smallest value of growth opportunity of 0.280400 or $28.04 \%$ is owned by Taisho Pharmaceutical Indonesia Tbk in 2013 which was at the mature stage with a market value of Rp.97.314.000.000 and book value of Rp. 347052274 000 . The biggest value of growth opportunity worth 46.13300 or $460.13 \%$ is owned by PT Multi Bintang Indonesia Tbk in 2013 which was at the mature stage 
with a market value of Rp.196.280.681.800.000 and book value of Rp. 4.254.670.000.000.

In the multiple regression analysis using panel data estimation, there are two kinds of methods that can be used, namely fixed effect and random effect approaches. To find the model that should be used, Hausman test was used. Hausman test was done to determine whether the model of fixed effect model or random effect model should be used in estimating the regression. Hausman test that generates chisquare statistical probability value smaller than the significance level $(\alpha=0.05)$ results in a decision that the fixed effect model is better to be used to estimate the panel data regression. Based on the results of data processing using Eviews software, the chi-square probability value was obtained for 0.0034 or less than the significance level $(\alpha=0.05)$. Thus, the fixed effect model is better than the random effect in estimating panel data regression.

The analysis in this study uses a multiple regression analysis with a dummy serving to determine the influence of the independent variables on the dependent variable. The analytical method used in this study is a panel regression model data.

The panel one produces the value of adjusted $\mathrm{R}$-squared of 0.499155 , meaning that the independent variables in the model can explain the dependent variable (leverage) of 0.499155 or $49.99 \%$. On panel one, there is a difference between the yield coefficient signs and the fourth hypothesis (the size of the company) and fifth hypothesis (non-debt tax shield). The regression results showed that the size of the company and non-debt tax shield have a positive impact seen from the coefficient signs and different hypotheses. The company size variable has a positive and insignificant influence so in the fourth hypothesis, $\mathrm{HO}$ is accepted. The variable of non-debt tax shield has a positive and significant impact. According to these results, there is no difference and the coefficient signs are consistent with the second (profitability), third (liquidity), sixth (asset tangibility), and seventh (growth opportunities) hypothesis, meaning that the influence of these variables is consistent with the hypothesis. The variable of profitability has a significant and negative effect so it can be said that in the second hypothesis $\mathrm{HO}$ is rejected. The variable of Liquidity has a negative and significant effect so in the third hypothesis $\mathrm{HO}$ is rejected. The variable of Asset tangibility has a significant and negative effect so in the sixth hypothesis $\mathrm{HO}$ is rejected. Besides, the variable of growth opportunity has a significant and positive effect so in the seventh hypothesis $\mathrm{HO}$ is rejected.

In panel two, the variable of the life cycle has a value of -0.136171 and significant coefficient. This means the division of the life cycle has an influence in the decision of leverage or capital structure of the company. Other variables have the same value as previously mentioned showing that there are differences in the results with the fourth (the size of the company) and fifth (non-debt tax shield) hypothesis. Besides, there is no difference in the coefficient signs and this is in accordance with the second (profitability), third (liquidity), sixth (asset tangibility), and seventh (growth opportunities) hypothesis. The variables influencing profitability, liquidity, the size of the firm, non-debt tax shield, asset tangibility and growth opportunities remain the same as in the panel one. The division of the company in accordance with the life cycle generates the Adjusted R-squared value of 0.586808 which is higher than not making the division in accordance with the life cycle that is 0.499155 . It can be said that by dividing the company in accordance with the life cycle may explain the leverage or capital structure of the company better.

Panel three until panel five are the result of regression conducted in accordance with the company's life cycle. Panel three is for companies at the stage of introduction, panel four for companies at the growth stage, and panel five for companies at a mature stage. The division is intended to know differences in the variables influencing the decision of leverage or capital structure of the company at any life cycle. It turned out that, according to the results of panel three to panel five, there is no difference in variables influencing the decision of leverage or capital structure of the company. The result remains the same as the previous panel stating that there is a difference between in coefficient sign between the result and the fourth (the size of the company) and fifth (non-debt tax shield) hypothesis. The regression results showed that the size of the company and non-debt tax shield 
JURNAL BISNIS \& MANAJEMEN

ISSN 1412 - 3681

have a positive impact seen from the coefficient sign and different hypotheses. The variable of company size has a positive but insignificant influence so the $\mathrm{HO}$ in the fourth hypothesis is accepted. The variable of non-debt tax shield has a positive and significant impact.

According to the results, there is no difference in the coefficient sign and it is consistent with the second (profitability), third (liquidity), sixth (asset tangibility), and seventh (growth opportunities) hypothesis meaning that the influence of these variables is consistent with the hypothesis. The variable profitability has a significant and negative effect so it can be said $\mathrm{HO}$ in the second hypothesis is rejected. The variable of Liquidity has a negative and significant effect so it can be said that $\mathrm{HO}$ in the third hypothesis is rejected. Asset tangibility has a significant and negative effect so it can be said that $\mathrm{HO}$ in the sixth hypothesis is rejected, the growth opportunity has a significant and positive effect so it can be said that $\mathrm{HO}$ in the seventh hypothesis is rejected.

Below is presented the results of this study compared to the results of previous research and also the links with the theories and facts.

\section{The Influence of Company Life Cycle on Leverage}

The life cycle, as mentioned earlier, is a stage in the life of a company. The company's activity can be investigated in accordance with the life cycle. The life cycle of a company is not a new thing in management science because it has been developed in strategic management. Based on some research, the life cycle is one of the variables that can reasonably explain the leverage decision of a company.

Based on this research, the life cycle has a negative and significant coefficient. Thus it can be said that the division of the life cycle has an influence on the leverage decision or capital structure of a company. The negative coefficient explains that the companies which are in the cycle of introduction will have a greater leverage than in other stages, and the mature stage has a smaller leverage than in other stages of life cycle.

These results are consistent with previous studies presented by Castro et al (2012) describing the company's capital structure decision in accordance
Jurnal Bisnis \& Manajemen, 2017, Vol. XVIII, No. 1, 46-54

with the cycle. They explained that the cycles have an important role in explaining the company's capital structure decisions.

\section{The Influence of Profitability on Leverage}

Based on the research results, profitability has a negative effect on leverage. This result is in accordance with some of the previous research, namely Myers (1993) and Strebulaev (2007) describing that when a company has a high profitability, it would reduce the possibility of that company to owe in running its business activities. Brigham and Houston (2004: 505) also explained that when the companies have a very high rate of return, they will finance most of their funding needs with the internally generated funds.

This result is consistent with the pecking order theory which states that every increase in profitability will be followed by a decrease in leverage. This is because if the profit increases, the company reduces or does not need to increase the use of debt due to the funding requirements can be obtained from internal, that is from retained earnings. If the company has a high ability to generate funds, the company shall have sufficient sources of internal funds to finance the operations.

\section{The Influence of Liquidity on Leverage}

Liquidity is one of the factors taken into account in capital structure decisions. Companies that have a high liquidity will not tend to use of debt financing. Based on the research results, liquidity negatively affects leverage. This result is in accordance with some previous research stating that when the liquidity is high, the leverage will decline (Bennet and Donnelly 1993, Ozkan 2001, and Akdal 2011).

This result is consistent with the pecking order theory which states that every increase in liquidity will be followed by a decrease in leverage. This is because if a company has a high level of liquidity, it will have the large internal funds to be used to finance the investments prior to using external financing such as debt.

\section{The Influence of Company Size on Leverage}

The results showed that the size of the company has a positive effect on leverage but not significant. This positive effect is in line with Fama and French (2005) 
explaining that the size of the company will be seen as the ability of the company to make debt. The greater the debt is, the larger the firm should be. This result is not in line with Ramlall (2009) explaining that the big companies have a lower leverage due to the higher information asymmetry and complex structure. The big companies tend to have strong financial resources from retained earnings to finance their operations. This result is not in line with Hadianto (2008) and Mela (2011).

Thus, the results of this study do not correspond with the pecking order theory. Pecking order theory explains that the size of the company will negatively affect leverage.

\section{The Influence of Non-Debt Tax Shield on Leverage}

Non-debt tax shield is a non-cash charge leading to tax savings and acts as capital to reduce debt. From the research results, it was found that nondebt tax shield has a positive effect on leverage. This is consistent with the research of Bennett and Donelly (1993) explaining that non-debt tax shield has a positive effect on leverage. This positive effect of non-debt tax shield is seen as the company's ability to go into debt, the greater the non-debt tax shield is, the greater leverage is. The results of this study are not consistent with Bradley, Jarrel, and Kim (1984) finding the type of non-debt tax shield in the form of depreciation. The tax saving is not just from the interest payments as a result of debt use but also from the depreciation and amortization. The greater depreciation and amortization are, the larger the income tax savings and the cash flow become. Therefore, a company that has a high non-debt tax shield tends to use a lower level of debt.

Thus, the result of this research showed that nondebt tax shield has a positive effect and is not in line with the pecking order theory. Pecking order theory explains that non-debt tax shield negatively affects leverage.

\section{The Influence of Asset Tangibility on Leverage}

Results of the study showed that the asset tangibility has a significant and negative effect on leverage. The results are consistent with Christianti (2006) who found that there is a negative influence of asset tangibility on the level of leverage. The result supports the pecking order hypothesis explaining that if a company has a higher asset tangibility, it would prefer internal financing to fund the operation obtained from the earnings. It is also in line with Seftianne and Handayani (2011) who found that asset tangibility has a negative effect on the capital structure. The higher the asset tangibility is, the lower the capital structure becomes, vice versa.

Based on the discussion above, it can be concluded that this study supports the pecking order theory. Pecking order theory states that the structure of asset has a negative effect on leverage.

The Influence of Growth Opportunities on Leverage The result of this study is in accordance with the initial hypothesis stating that the growth of the company positively affects capital structure. It is clear that the more rapid the growth rate is, the larger the leverage capacity becomes.

The result is consistent with Darminto and Manurung (2008) who found that the company's growth has a positive but not significant effect on the level of leverage. This result also supports the pecking order hypothesis. The companies with high growth opportunities will likely require the debt to acquire more assets. In the pecking order behavior, the growth has a positive effect on debt. Not all companies with a good growth have sufficient funds to finance their projects. The new companies and the companies with a high growth rate typically do not have sufficient funds to finance their projects. Thus the companies will look for the sources of funding, especially from debt to run the projects. This certainly supports the pecking order theory where debt is more preferred than the issuance of new shares as external financing. The companies which are growing have a large demand for funds. Therefore, the companies need funds from debt if the internal financing is insufficient.

Based on the discussion above, it can be concluded that this study supports the pecking order theory. Pecking order theory explains that the growth opportunities have a positive effect on leverage.

\section{CONCLUSION AND RECOMMENDATION}

This study aims to determine the effect of the division 
JURNAL BISNIS \& MANAJEMEN

ISSN 1412 - 3681

of the company's life cycle, profitability, liquidity, company size, non-debt tax shield, asset tangibility and growth opportunities on leverage or capital structure decision in the consumer goods companies listed on the Indonesia Stock Exchange in 2007- 2011. Based on the results of data analysis and discussion, it can be concluded that the division of the company's life cycle has a significant influence on the decision of leverage.

Profitability has a negative and significant effect on leverage. This result is consistent with the pecking order hypothesis which states that the greater the profitability is, the smaller the chance for the company to use debt.

It is also concluded that liquidity has a negative and significant effect on leverage. So, this research supports the hypothesis pecking order stating that the higher the liquidity is, the smaller the chance for the companies to use debt.

Firm size has a positive influence on leverage even though not significantly. So, this result is not consistent with the pecking order hypothesis. This result suggests that the larger the company is, the greater the debt of the company is.

Non-debt tax shield has a positive and significant effect on leverage. So, this result is not consistent with the pecking order hypothesis. This result suggests that the larger the company is, the greater chance for the company to use of debt will be.

Asset tangibility negatively and significantly affects leverage. So, this result supports the pecking order hypothesis stating that the greater the asset tangibility is, the smaller the chance for the companies to use debt.

Finally, the growth opportunities have a positive and significant effect on leverage. So, this research result is consistent with the pecking order hypothesis which states that the higher the growth is, the higher the debt of the company will be.
Jurnal Bisnis \& Manajemen, 2017, Vol. XVIII, No. 1, 46-54

\section{REFERENCE}

Akdal, S. (2011). How do firm characteristics affect capital structure? Some UK evidence, Working Paper SSRN March.

Bennett, M., and Donnelly, R. (1993). The Determinants of Capital Structure: Some UK Evidence. British Accounting Review, Vol.25 No.1, Page 43-59.

Bradley, M., Jarrell, G.A., and Kim, E.H. (1984). On the existence of an optimal capital structure: Theory and evidence. The Journal of Finance, Vol.39 No.3, Page 857-878.

Brigham, E.F \& Houston, J.F. (2004). Fundamentals of Financial Management. Tenth Edition. USA, Thomson: Southwestern.

Bulan, L.T. and Yan, Z. (2010). Firm maturity and the pecking order theory. Working Paper, August.

Christianti, Ari. (2006). Penentuan Perilaku Kebijakan Struktur Modal Pada Perusahaan Manufaktur Di Bursa Efek Jakarta: Hipotesis Static Trade Off AtauPecking Order Theory.

Darminto, and Manurung, Adler. (2008). Pengujian teori trade-off dan teori pecking order dengan satu model dinamis pada perusahaan publik di Indonesia. Universitas Indonesia.

Dickinson, V. (2011). Cash Flow Patterns as a Proxy for Firm Life Cycle. The Accounting Review, vol.86 No.6, Page 1969-1994.

Fama, E.F., and French, K.R. (2002). Testing trade-off and pecking order predictions, about dividends and debt. Review of Financial Studies, Vol.15 No.1, Page 1-33.

Frank, M.Z., and Goyal, V.K. (2009). Capital structure decisions: Which factors are reliably important?. Financial Management, vol.38 No.1, Page 1-37. 
Hadianto, Bram. (2008). Pengaruh struktur sktiva, ukuran perusahaan, dan profitabilitas terhadap struktur modal emiten sektor telekomunikasi periode 2000-2006: sebuah pengujian hipotesis pecking order.

Mela, (2011). Pengaruh Likuiditas, Ukuran Perusahaan dan Tingkat Bunga terhadap struktur modal pada perusahaan LQ45 di BEI. Universetas Diponegoro.

Myers, S.C. (1984). The capital structure puzzle. The Journal of Finance, vol.39 No.3, Page 575592.

Ozkan, A. (2001). Determinants of capital structure and adjustment to long run target: Evidence from UK company panel data. Journal of Business Finance and Accounting, Vol.28, Page 175-198.
Ramlall, Indranarain. (2009). Determinants of Capital Structure among Non-Quoted Mauritians Firm Under Specificity Of Leverage: Looking For A Modified Pecking Order Theory. Journal of Finance and Economic, No.31

Seftianne and Handayani. (2011). Faktor-faktor yang mempengaruhi struktur modal pada perusahaan publik sektor manufaktur. Jurnal bisnis dan akuntansi vol.13, No 1, April, Page 39-56

Strebulaev, I.A. (2007). Do tests of capital structure theory mean what they say? Journal of Finance, vol.62 No.4, Page 1747-1787.

Titman, S. and Wessels, R. (1988). The determinants of capital structure choice, Journal of Finance, Vol. 43, pp. 1-19 